International Review of Research in Open and Distributed Learning Volume 20, Number 5

December - 2019

\title{
Strategies to Assist Distance Doctoral Students in Completing Their Dissertations
}

Janine Lim, Duane Covrig, Shirley Freed, Becky De Oliveira, Mordekai Ongo, and Isadore Newman Andrews University

\begin{abstract}
Completing doctoral dissertations is difficult work and may be harder for distance students physically separated from institutional and collegial supports. Inability to complete independent research contributes to doctoral student attrition. Factors impacting completion include institutional factors, student characteristics, and supervisory arrangements (Manathunga, 2005). This paper shares proactive strategies used by a Midwestern university in the United States to support distance doctoral students. Strategies and technology tools are described that (a) cultivate a shared culture of responsibility and commitment, (b) increase effective communication between researchers, and (c) grow departmental and institutional services and technologies for faculty and students. This paper suggests the use of a specific framework to help students develop a shared culture of responsibility. This framework encourages students to discuss their social network, as well as teaches students how to manage their split life by using a tool which evaluates a student's readiness for the dissertation process and maps out where dissertation skills and knowledge are developed throughout the program. Strategies for effective communication include availability, effective feedback, trust, and humor. Services and technologies provided to build capacity include the use of online and library resources, campus-wide use of research software, writing and research services, and department supports and processes to promote student research. These mechanisms for accountability, mentoring, training, and trust increase the likelihood of success.
\end{abstract}

Keywords: dissertation completion, distance doctoral students, graduate student services, online doctoral programs 


\section{Introduction}

Writing a dissertation is a grueling experience. In fact, in the United States, about half of prospective doctoral candidates fail to advance beyond all-but-dissertation (ABD) status (Ali, Kohun, \& Levy, 2007; J airam \& Kahl, 2012; Lovitts, 2001, 2007; Walker, Golde, J ones, Bueschel, \& Hutchings, 2008). While 40$50 \%$ of students in traditional doctoral programs don't complete, distance doctoral students are dropping out of their programs at rates 10-20\% higher than students in traditional programs (Terrell, Snyder, \& Dringus, 2009). This attrition rate may be higher for women and minorities (Lovitts, 2001). Imagine students' disappointment at having spent years of work and significant finances toward an unfinished degree. The reality can be discouraging - both in regards to the way that the problem is kept invisible and the reality of its extensiveness-which has generated calls for changes, motivating someindividuals, groups, and researchers to use their research to find attrition reducing solutions (Lovitts, 2007; Lovitts \& Wert, 2009; Maki \& Borkowski, 2006; Ross, Gallagher, \&Macleod, 2013).

The Council of Graduate Schools has produced four reports related to challenges and innovations attempting to improve doctoral completion rates (King, 2008; Sowell, 2008, 2009; Sowell, Zhang, Bell, \& Kirby, 2010). They have provided suggestions on how to improve six areas: administrative processes, admissions, advising, program environment, financial support, and research (Sowell et al., 2010). This article focuses primarily on the advising and program environment suggested by Sowell. Strategies of shared responsibility, commitment, communication, and institutional services and technologies are discussed.

The authors of the research paper at hand work at a small Midwestern university (about 3400 online and on-campus students). Twenty faculty members in the School of Education consistently serve over 125 doctoral students at the dissertation stage, graduating an average of 12 - 15 doctoral students each year for the past two decades. Many of those graduates have been a part of the university's Leadership program an innovative, competency-based program started in 1994. Over the years, useful strategies to support doctoral students may have resulted in generally higher than normal (Terrell et al., 2009) success rates over the first 15 years of the Leadership program, as shown in Table 1. 
Table 1

Doctoral Student Graduation Rates

\begin{tabular}{cccc}
\hline $\begin{array}{c}\text { Year of cohort } \\
\text { starting }\end{array}$ & Starting participants & $\begin{array}{c}\text { Graduated participants } \\
\text { since start year }\end{array}$ & Completion rate \\
\hline 1994 & 19 & 12 & $63 \%$ \\
1995 & 20 & 16 & $80 \%$ \\
1996 & 11 & 10 & $91 \%$ \\
1997 & 8 & 7 & $88 \%$ \\
1998 & 17 & 13 & $76 \%$ \\
1999 & 19 & 14 & $74 \%$ \\
2000 & 26 & 18 & $69 \%$ \\
2001 & 16 & 14 & $88 \%$ \\
2002 & 12 & 9 & $75 \%$ \\
2003 & 29 & 22 & $76 \%$ \\
2004 & 23 & 13 & $57 \%$ \\
2005 & 11 & 6 & $55 \%$ \\
2006 & 22 & 19 & $86 \%$ \\
2007 & 19 & 14 & $74 \%$ \\
2008 & 9 & 8 & $89 \%$ \\
2009 & 6 & 5 & $83 \%$ \\
\hline
\end{tabular}

The $\mathrm{PhD}$ Leadership program is job embedded, which is more common for master's level programs than doctoral level programs (Bondy, Shannon, Eda, \& Munarriz-Diaz, 2017; Duesbery, Frizelle, Twyman, Naranjo, \& Timmermans, 2019), and requires students to remain in full-time employment to allow their jobs to function as platforms for research and the development of leadership competencies. This connection to work enables students to continue with their employment and family responsibilities without relocating to the university for onsite education while working toward their $\mathrm{PhDs}$. This program advantage attracts many working professionals. The downside of this program is the reduced time for research and writing, and sometimes the lack of support and face to face time with faculty (Kennedy, Terrell, \& Lohle, 2015). However, institutional cultures that accommodate distance doctoral students have been recognized as having the potential to increase student persistence and success (Terrell et al., 2009).

The founding faculty members designed the program based on social constructivist principles (Vygotsky \& Cole, 1978), a set of principles that are rooted in the belief that individuals actively participate in the creation of their knowledge by interacting with diverse learners. The unique and atypical components of the program that demonstrate the faculty's commitment to social constructivism are: the Leadership and Learning Groups, the Leadership and Learning Plan where participants design their own program of studies, and the required on-campus Annual Leadership Conference. Each of these components provides unique opportunities for participants to interact with others to move toward the completion of their program. 
The approach to dissertation support in this program is multifaceted and has arisen from an analysis of the challenges, feedback, and successes of the participants. The strategies documented in this paper focus on three primary areas impacting success rates in this doctoral program: building a shared responsibility and commitment, increasing effective communication between student and faculty researchers, and constructing departmental and institutional services for both students and faculty.

\section{Shared Responsibility and Commitment}

The fundamental first step to creating a culture of shared responsibility is recognizing the completion/ attrition issue as a shared problem. Faculty convey the truth that faculty and institutions share the journey with students. When both students and faculty are committed to learning the skills needed to complete a dissertation, a positive environment is created for dissertation completion. In this section, four approaches to help develop shared responsibility and commitment are reviewed including: (1) a tool to discuss the distance doctoral student's social network, (2) teaching students how to manage their split life, (3) a tool to evaluate the student's readiness for the dissertation process, and (4) mapping out where dissertation skills are developed in the program.

\section{Distance Doctoral Student's Social Network}

A social network with clear roles is a crucial starting point for talking about the expectations and boundaries of responsibility. Students need to be connected to a caring collective of people and resources (Dombroski et al., 2018; Fahlman, 2009; J airam \& Kahl, 2012). Table 2 presents a brief overview of one tool useful for facilitating dialogue with students regarding how others share their journey. Although the dissertation process will often feel like the loneliest aspects of a graduate students' work, in reality, without a social network, few people find the resolve to finish. The social network consists of individuals outside and inside the university. Family, friend, and work social networks become crucial for giving deep emotional support as well as financial and practical support (van Rhijn, Murray, \& Mizzi, 2018; Williams, Wall, \& Fish, 2019). Social networks inside the university contribute to technical skill development as well as academic and intellectual development necessary to finish. Besides the traditional university social network, students in this program are required to participate in a Leadership and Learning Group, which, as seen in other online doctorial programs (Denman, Corrales, Smyth, \& Craven, 2018; Kumar, Dawson, Black, Cavanaugh, \& Sessums, 2011) creates additional support and motivation. Students also annually return to campus for the Roundtable Conference, where they network with faculty and peers and attend required workshops and optional research camps. Returning to campus is an essential component of the program, providing social networking opportunities and support to distance students and increasing the number of professional friends that students have to support them in their doctoral journey (Grady, 2016; Williams et al., 2019). 
Table 2

Social Network and Role in the Dissertation

\begin{tabular}{|c|c|c|c|}
\hline People & Role played & $\begin{array}{l}\text { Distance doctoral student } \\
\text { expectations of the social } \\
\text { network }\end{array}$ & $\begin{array}{l}\text { Social network expectations } \\
\text { of distance doctoral student }\end{array}$ \\
\hline
\end{tabular}

Outside the university

Immediate

family and

close friends
Concern for student's

holistic self, guarding the

student's schedule,

providing a break

Boss, employer, May provide accountability,

coworkers,

employees

$\begin{array}{ll}\text { Chair } & \begin{array}{l}\text { Main mentor for the } \\ \text { dissertation, provides } \\ \text { feedback, provides } \\ \text { assistance with decisions on } \\ \text { methods, content, and } \\ \text { interpretation }\end{array} \\ \begin{array}{ll}\text { Committee } \\ \text { member: }\end{array} & \begin{array}{l}\text { Expert mentor, theoretician } \\ \text { Content }\end{array} \\ \begin{array}{l}\text { Committee } \\ \text { member: } \\ \text { Method }\end{array} & \begin{array}{l}\text { Methodologist, statistician } \\ \text { Faculty of } \\ \text { research and } \\ \text { content courses }\end{array} \\ \begin{array}{l}\text { Instruction in research } \\ \text { methods, literature reviews, } \\ \text { data analysis methods, } \\ \text { provide background and } \\ \text { theory }\end{array}\end{array}$

Love, slack from other duties, understanding, encouragement, trust

Flexibility, understanding, encouragement
Focus on the dissertation, completion, normal will return, respect of their contribution to success

No drop-in productivity, completion
Has read extensively in the field of study, provides assistance with literature and theories

Provide guidance on data collection and analysis, and methods related to research questions

Guidance and resources in writing dissertation proposal, provide structure for reading and writing, support in transition to self-directed research, transition course work and reading into research plan
Receive feedback well, show ownership and individual initiative, share clear arguments in defense of work, keep in communication, avoid complaining Listen and adapt to advice, collect and read literature, write the literature based on advice

Read about methods beyond assigned courses, take additional methods courses as needed

Acquire and manage literature collection, find and use technology, take initiative, improve writing 
Fellow students Colleagues in research informal, as journey

well as leadership and learning groups (L\&L Groups)
Meet regularly; provide feedback, ideas on content, methods, analysis; share stories of endurance, encouragement
Meet regularly, share material, be honest about challenges, ask for assistance, timely production of material, sharing tips

\section{Time Management}

Another useful discussion to facilitate with distance doctoral students regards the reality of their own "split" lives while working on a dissertation. Finding the balance between doctoral work and life is particularly challenging for mature students (Fung, Southcott, \& Siu, 2017). Discussing this challenge encourages students to acknowledge the difficulty of creating time for everything in their lives. Students and faculty discuss what hobbies they will set aside and what new habits (better sleep, exercise schedules, eating plans, etc.) can make their work more efficient. As students consider their split lives, they can carve out time slots to work consistently on their dissertation. Small chunks of regular time prove effective for students and researchers alike (Bolker, 1998; Silvia, 2007). Faculty teach students how to divide dissertation tasks into "high focus" and "low focus" tasks. Students can then assess their mental state and select dissertation tasks accordingly. High focus tasks may include writing new text, reading, or analyzing data. Low focus tasks include downloading PDFs of journal articles and cleaning references in reference management software. Such strategies can increase a distance doctoral student's commitment and sense of shared responsibility.

\section{Doctoral Student's Dissertation Readiness}

An evaluation tool to assess students' readiness for the dissertation focuses the student's attention on the immediate dissertation tasks. Self-evaluation contributes to building a foundation of shared responsibility and commitment to each task and is a key component of this distance doctoral program (Alaby, 2002; Freed, Covrig, \& Baumgartner, 2010). Figure 1 shows one example of a Likert scale evaluation that faculty use to guide students through considering their readiness for the dissertation phase, and toward working on specific tasks in preparation for beginning their dissertation.

\begin{tabular}{|c|c|c|c|c|c|}
\hline \multicolumn{6}{|c|}{$\begin{array}{l}\text { DISSERTATION PROPOSAL READINESS EVALUATION } \\
\text { Indicate level of readiness with an } \mathrm{x} \text { from Low ................ High }\end{array}$} \\
\hline $\begin{array}{l}\text { 1. Previous reading on a specific } \\
\text { area. } \\
\text { You cannot write a good dissertation } \\
\text { without the advice of others. Much of } \\
\text { this wisdom comes from reading journal } \\
\text { articles and well-chosen books and } \\
\text { contacting experts and asking the right } \\
\text { questions. The goal is to build on other's } \\
\text { work. Most dissertation bibliographies } \\
\text { have } 100-200 \text { references. How much } \\
\text { have you read on your particular area of } \\
\text { research? }\end{array}$ & \begin{tabular}{l}
\multicolumn{1}{c}{$\mathbf{1}$} \\
10 articles/ \\
books
\end{tabular} & \begin{tabular}{l}
\multicolumn{1}{c}{$\mathbf{2}$} \\
50 \\
articles/ \\
books
\end{tabular} & \begin{tabular}{l}
\multicolumn{1}{c}{$\mathbf{3}$} \\
100 \\
articles/ \\
books
\end{tabular} & \begin{tabular}{l}
\multicolumn{1}{c}{$\mathbf{4}$} \\
150 \\
articles/ \\
books
\end{tabular} & \begin{tabular}{l}
\multicolumn{1}{c}{$\mathbf{5}$} \\
200 \\
articles/ \\
books
\end{tabular} \\
\hline $\begin{array}{l}\text { 2. Literature search, review and } \\
\text { synthesis. }\end{array}$ & $\begin{array}{r}\mathbf{1} \\
\text { Search }\end{array}$ & 2 & 3 & 4 & 5 \\
\hline
\end{tabular}




\begin{tabular}{|c|c|c|c|c|c|}
\hline $\begin{array}{l}\text { Do you know how to search and retrieve } \\
\text { material from the university library } \\
\text { databases, ERIC, and other public } \\
\text { databases? Have you signed up for Table } \\
\text { of Contents updates of key journals and } \\
\text { publisher databases? Do you know how } \\
\text { to systematically review literature, write } \\
\text { an article or book review, and synthesize } \\
\text { conflicting and complex literature? }\end{array}$ & database & & & & $\begin{array}{l}\text { Synthesize } \\
\text { complex } \\
\text { literature }\end{array}$ \\
\hline $\begin{array}{l}\text { 3. Research topic / title / problem / } \\
\text { purpose / research questions. } \\
\text { You have a focused understanding of } \\
\text { what you are studying, the data you } \\
\text { need, why the study matters, and how to } \\
\text { accomplish it, as well as clear integration } \\
\text { and consistency across these five areas. }\end{array}$ & $\begin{array}{c}\mathbf{1} \\
\text { Have } 1 \text { or } 2\end{array}$ & 2 & $\begin{array}{c}\mathbf{3} \\
\text { Have } \\
\text { draft } \\
\text { of all } 5\end{array}$ & 4 & $\begin{array}{c}\mathbf{5} \\
\text { All } 5 \text { with } \\
\text { integration }\end{array}$ \\
\hline $\begin{array}{l}\text { 4. Qualitative research knowledge, } \\
\text { training, and skills. } \\
\text { Avoid the minimalist view, i.e. "How } \\
\text { little research can I learn to get through } \\
\text { the dissertation?" Those who secure a } \\
\text { doctorate are looked upon as individuals } \\
\text { with special } \\
\text { wisdom, discretion, advanced skills of } \\
\text { analysis, and the ability to detect } \\
\text { falsehood. Research is a wonderful } \\
\text { analysis tool for life, work, writing a } \\
\text { dissertation. }\end{array}$ & $\begin{array}{l}\quad 1 \\
\text { Adequate } \\
\text { knowledge } \\
\text { to read and } \\
\text { evaluate } \\
\text { qualitative } \\
\text { papers }\end{array}$ & 2 & 3 & 4 & $\begin{array}{l}\quad \mathbf{5} \\
\text { Deep } \\
\text { knowledge } \\
\text { about the } \\
\text { specific } \\
\text { method for } \\
\text { your } \\
\text { research }\end{array}$ \\
\hline $\begin{array}{l}\text { 5. Quantitative research } \\
\text { knowledge, training, and skills. } \\
\text { Avoid a minimalist approach. Doctoral } \\
\text { students in the social sciences are } \\
\text { expected to be able to interpret } \\
\text { quantitative data, including: survey } \\
\text { validation; instrumentation; } \\
\text { experimental or correlational design; } \\
\text { use of parametric and non-parametric } \\
\text { tests of significance, ANOVA, path } \\
\text { analysis, and other statistical } \\
\text { techniques. }\end{array}$ & \begin{tabular}{l}
\multicolumn{1}{c}{$\mathbf{1}$} \\
Adequate \\
knowledge \\
to read and \\
evaluate \\
quantitative \\
papers
\end{tabular} & 2 & 3 & 4 & $\begin{array}{l}\quad \mathbf{5} \\
\text { Deep } \\
\text { knowledge } \\
\text { about the } \\
\text { specific } \\
\text { method for } \\
\text { your } \\
\text { research }\end{array}$ \\
\hline $\begin{array}{l}\text { 6. Passion and commitment. } \\
\text { Hard work needs fuel and a clear and } \\
\text { steady passion. How much fuel do you } \\
\text { have? Is the tank full? }\end{array}$ & $\begin{array}{l}\text { 1 } \\
\text { Some } \\
\text { passion }\end{array}$ & 2 & 3 & 4 & \begin{tabular}{l}
\multicolumn{1}{c}{$\mathbf{5}$} \\
Driven, \\
high value, \\
clear vision
\end{tabular} \\
\hline $\begin{array}{l}\text { 7. Relationship with dissertation } \\
\text { chair and committee. } \\
\text { Dissertations are the product of a } \\
\text { scholarly community. Trust and good } \\
\text { communication between the researcher }\end{array}$ & $\begin{array}{l}\text { 1 } \\
\text { Three } \\
\text { names }\end{array}$ & \begin{tabular}{l}
\multicolumn{1}{c}{$\mathbf{2}$} \\
Talked \\
with all \\
three
\end{tabular} & $\begin{array}{l}\quad \mathbf{3} \\
\text { Emergent } \\
\text { trust }\end{array}$ & 4 & \begin{tabular}{l}
\multicolumn{1}{c}{$\mathbf{5}$} \\
Call often; \\
get quick \\
feedback; \\
work
\end{tabular} \\
\hline
\end{tabular}




\begin{tabular}{|c|c|c|c|c|c|}
\hline $\begin{array}{l}\text { and the chair are essential. How well } \\
\text { connected are you? }\end{array}$ & & & & & $\begin{array}{l}\text { through } \\
\text { conflict }\end{array}$ \\
\hline $\begin{array}{l}\text { 8. Resources (financial, social, } \\
\text { emotional, physical, mental). } \\
\text { Time, energy, space, money, and social } \\
\text { understanding all assist in the journey. } \\
\text { When one or two are missing, it is } \\
\text { harder. }\end{array}$ & 1 & 2 & 3 & 4 & $\begin{array}{l}\quad \mathbf{5} \\
\text { Full time; } \\
\text { \$ for data } \\
\text { collection; } \\
\text { good } \\
\text { health }\end{array}$ \\
\hline $\begin{array}{l}\text { 9. Graduate writing ability. } \\
\text { All right, poetry is more fun to write, but } \\
\text { this is a dissertation. Skills are needed in } \\
\text { technical writing and the precision of } \\
\text { research. Extra points if you write } \\
\text { enjoyable as well as readable APA cited } \\
\text { and institution-formatted prose. }\end{array}$ & 1 & 2 & 3 & 4 & \begin{tabular}{l}
\multicolumn{1}{c}{$\mathbf{5}$} \\
Had thesis \\
in MA; \\
review \\
published
\end{tabular} \\
\hline
\end{tabular}

Figure 1. Dissertation proposal readiness evaluation.

\section{Curriculum Mapping}

Finally, since the 1990's the faculty began mapping out the specific courses or experiences within which participants developed the research skills to complete a dissertation, a method also used by Breen and Martin (2018) and Garcia and Yao (2019). The program requires the typical courses like proposal development, and qualitative and quantitative research methods. However, unique aspects of the program, specifically the Leadership and Learning Plan, Leadership and Learning Groups, Writing Retreats and Annual Roundtables presented special opportunities for research development. The structure of these faceto-face gatherings provided opportunities for just-in-time-learning and students came with a readiness to learn. Participants were ready to apply the information directly to their dissertation work rather than simply completing a course requirement. Developing a sense of shared responsibility and commitment is key to building an effective relationship between the dissertation committee and the distance doctoral student. The tools and strategies shared in this section are used by faculty to focus the conversation with students, cultivating the student's capacity for the dissertation journey.

\section{Effective Communication between Researchers}

Isolation is a normal challenge for scholars, but it is a challenge that is particularly intense for the distance doctoral student (Ali \& Kohun, 2006; Deem \& Brehony, 2000). Effective communication between researchers can prevent problems that may otherwise emerge due to working in isolation. Manathunga (2005) found that experienced research supervisors identified: (1) changing the topic, (2) avoiding communication, (3) isolating themselves, and (4) not submitting work, as key warning signs that students were experiencing difficulties. Kearns, Gardiner, and Marshall (2008) recognized seven self-handicapping behaviors impeding graduate student work: overcommitting, busyness, perfectionism, procrastination, disorganization, limited effort, and the choice of performance-debilitating circumstances. These warning signs can be viewed through the lens of ineffective communication. An intentional focus on planning and 
implementing effective communication includes strategies of availability, effective feedback, trust, and humor.

\section{Availability}

Students working on dissertations express concern regarding the availability of their supervising faculty (Harrison, Gemmell, \& Reed, 2014). Availability begins with the supervising researcher and the distance doctoral student negotiating communication methods and response times. Understanding and teaching may go both ways, with the distance doctoral student sometimes taking the lead by asking for communication methods and modeling adaptability themselves. Faculty can respond quickly to emails with information regarding when detailed feedback will be forthcoming, providing the student with a sense of faculty immediacy (Baker, 2010; Kumar et al., 2011). Regularly scheduled meetings can bridge the distance, generating continuity and productivity. Faculty can also assist students in breaking up the project into smaller parts, which can overcome procrastination due to statistics anxiety (Onwuegbuzie, 2004). Tools such as phone, videoconference, e-mail, and even texting for very quick questions, can decrease the distance.

\section{Effective Feedback}

Short, frequent feedback is essential for effective communication and teaching (Berry, 2017; Walters \& Henry, 2016). Some faculty may struggle to give regular feedback because they believe they must read the whole manuscript first. Shorter feedback allows for quicker turnaround and paces students with limited corrections to handle quickly. For example, faculty should ensure students have a tight consistency between title, problem, purpose, and research questions early in the process (Newman \& Covrig, 2013). Tools such as the form in Figure 2 assist students in focusing faculty feedback.

\section{Dissertation Topic Guidelines}

Use this outline to develop your dissertation topic and facilitate the conversation with your prospective chair and as you recruit other committee members. You will be expected to attach the completed dissertation topic prospectus to your completed Dissertation Topic and Committee Form. The prospectus should be succinct, about 1-2 pages.

\begin{tabular}{|c|c|c|}
\hline Area & Evaluation Scale & Score \\
\hline 1. Title & $\begin{array}{l}\text { 1. Reflects something about the main topic } \\
\text { 2. Includes a few: key variables, population/ sample, or research design } \\
\text { 3. All variables, sample, research design issues evident in title }\end{array}$ & \\
\hline 2. Committee & $\begin{array}{l}\text { 1. Identifies chair } \\
\text { 2. Methodologist secured } \\
\text { 3. Complete committee agreed, vita of non-home-institution faculty } \\
\text { included }\end{array}$ & \\
\hline 3. Problem & 1. Mentions area of problem without much focus & \\
\hline
\end{tabular}




\begin{tabular}{|c|c|c|}
\hline (2-3 sentences) & $\begin{array}{l}\text { 2. Described problem } \\
\text { 3. Compelling problem / need stated }\end{array}$ & \\
\hline $\begin{array}{l}\text { 4. Purpose } \\
\text { (2-3 sentences) }\end{array}$ & $\begin{array}{l}\text { 1. Vague explanation of purpose } \\
\text { 2. Clearer description of purpose (explore, describe, correlate, etc.) } \\
\text { 3. Identifies major goal of study and the proposed product(s) }\end{array}$ & \\
\hline $\begin{array}{l}\text { 5. Research } \\
\text { Questions } \\
\text { (1-3 listed) }\end{array}$ & $\begin{array}{l}\text { 1. General question about a general area of inquiry } \\
\text { 2. Specific questions } \\
\text { 3. Feasible, clear and researchable specific questions }\end{array}$ & \\
\hline $\begin{array}{l}\text { 6. } \text { Methods } \\
\text { (2-3 sentences) }\end{array}$ & $\begin{array}{l}\text { 1. Type of research design is apparent } \\
\text { 2. Design, sample, data collection and analysis clearly listed } \\
\text { 3. Readiness level to use the chosen research methodologies is indicated }\end{array}$ & \\
\hline $\begin{array}{l}7 . \\
\text { Bibliography } \\
\text { (topics/ areas } \\
\text { listed) }\end{array}$ & $\begin{array}{l}\text { 1. Vague topical areas listed but not clear } \\
\text { 2. Added details are given } \\
\text { 3. Specific topical areas, authors and resources are briefly listed }\end{array}$ & \\
\hline $\begin{array}{l}8 . \\
\text { Consistency / } \\
\text { Logic / } \\
\text { Alignment }\end{array}$ & $\begin{array}{l}\text { 1. Title, problem \& purpose, and research questions are stated, but do not } \\
\text { align consistently to reflect the logic of your study. } \\
\text { 2. Title, problem, purpose, and research questions reflect an emerging logic } \\
\text { but some elements are still not well aligned. } \\
\text { 3. Title, problem statement, purpose and research questions are } \\
\text { thoughtfully stated to reflect a consistent logic of your study. }\end{array}$ & \\
\hline $\begin{array}{l}\text { 9. Connection } \\
\text { to work / } \\
\text { program }\end{array}$ & $\begin{array}{l}\text { 1. Study is not embedded in work nor connected to program parameters. } \\
\text { 2. Study is embedded solidly in your work } \\
\text { 3. Study is connected well to program parameters. }\end{array}$ & \\
\hline $\begin{array}{l}\text { 10. Timeline } \\
\text { \& Budget }\end{array}$ & $\begin{array}{l}\text { 1. Vague or unrealistic timeline evident } \\
\text { 2. More realistic timetable with enumeration of key components to work } \\
\text { 3. Realistic timeline with possible contingencies noted }\end{array}$ & \\
\hline & Total Points & / 30 \\
\hline
\end{tabular}

Figure 2. Dissertation topic guidelines. 
Brief, frequent, actionable feedback, specific reading material, or explicit problem-solving advice all help students progress appropriately (Walters et al., 2015). Manathunga (2005) suggested "framing supervision as a collaborative problem-solving exercise, where students receive the message that they are not alone" in the dissertation process builds confidence (p. 230). Asking, "is that helpful?" can focus feedback for both faculty and student. Honest, formal, constructive feedback, without overreaction, can inspire trust and improvement. The annual Leadership Conference provides a venue where participants and faculty meet, update one another on research progress, and set the agenda for the coming year. In addition to faculty feedback, students need feedback from a community of practice with other students experiencing the same research process (Terrell et al., 2009), in the context of the Leadership and Learning Groups. Sometimes students need specific, detailed feedback; other times they need broad strokes. Faculty should discern when students need each type. Faculty should model thinking about research for the students, while keeping the responsibility for learning on the students. Students should establish, in writing, clear takeaways from feedback conversations and realistic expectations for moving forward with their research.

\section{Trust}

Trust is at the core of the communication process (Faranda, 2015). Listening to students' fears, needs, and wants indicates deep listening, and thus contributes to the building of trust between supervisor and student. When faculty share previous dissertations and published articles and show students they are committed to the whole journey, trust in faculty dissertation competence is established. Meeting with other students in a group can help new students trust the faculty member, as here, students can experience criticism as dialogue and watch other students receive feedback without defensiveness (Kumar \&Coe, 2017).

\section{Humor}

Finally, humor and stories can set students at ease (Goodboy, Booth-Butterfield, Bolkan, \& Griffin, 2015; Violanti, Kelly, Garland, \&Christen, 2018). The authors find the use of humor useful to create receptiveness to the tightness and precision of language necessary to explain statistics. Sometimes students are overwhelmed by lack of knowledge or direction. Humor, asking a simple question about the methods, or telling a story all work to mentally rest students, lessen their fears, and bring more positive emotions to the work.

Effective communication between researchers involved in the dissertation process can reduce the likelihood of dropout. Negotiating availability, providing feedback, building trust, and using humor and stories are strategies emphasized in this program.

\section{Services and Technologies for Students and Faculty}

Capacity development can be defined as a systematic and organic accumulation of resources and structures that strengthen participants' abilities to effectively complete research (Ross et al., 2013). Building capacity can enable students to feel closer to faculty members throughout the dissertation journey (Ross et al., 2013) Capacity development addresses several institutional factors affecting retention in doctoral programs including: the use of online and library resources, campus-wide use of research software, writing and research services, and departmental processes (Manathunga, 2005). 


\section{Libraries and Literature}

Student literature searching, reading, management, and reviewing starts with library orientation and continues with in-library services. Skills in critiquing and citing literature are developed through required courses.

\section{Software}

The search to identify better ways to serve distance doctoral students is constantly leading to new technological tools to support the $\mathrm{PhD}$ process (Aghaee et al., 2016). Multiple tools have been implemented at the authors' institution for managing the distance dissertation process, including online editing tools and technology useful at each student work phase. These tools allow for file exchange, e-mail, progress tracking, content sharing, and viewing of learning object repositories.

Endnote or other bibliographic software (EasyBib, Mendeley, Zotero, etc.) enhance the citation of references with features to search, organize, collaborate, curate full text, and connect socially around research. Such software must be introduced to students by educators, and educators are also responsible for teaching students how to use the software. Next, students must then follow through with actually making use of the software for their research. Distance doctoral students increase their odds of successful completion as they learn to use technology to support their development from the start to the end. Deliberately introducing useful technology tools early during orientation, and repeatedly reminding students of their usefulness in e-mails and newsletters increases utilization.

Synchronous communication tools such as AdobeConnect, FaceTime, GoToMeeting, Skype, and Zoom are essential for supporting the distance doctoral student, especially visual learners (Oregon, McCoy, \& Carmon-J ohnson, 2018; Wagner, Enders, Pirie, \& Thomas, 2016). Document sharing tools allow faculty members to monitor student work - reviewing how students are coding their interviews, listening to interviews students are analyzing, and reviewing how students are displaying their data. Using videoconferencing allows the faculty to assess the student's reception of the feedback (Naughton \& Redfern, 2002). Communication tools and conference calling can make meetings easier for dissertation committee members in diverse locations.

Document sharing tools and workspaces also support the dissertation process (Ames, Berman, \& Casteel, 2018). In the early stages before formatting is critical, a peer editing tool such as GoogleDocs provides opportunity for editing and commenting. The Microsoft Word review tools afford the ability to highlight sections and write comments and feedback. Some faculty prefer to use Adobe Acrobat or iPad apps for marking up, highlighting, and providing feedback to students. Document sharing, though, can quickly cause confusion and frustration with multiple versions of files. Using a tool like DropBox to keep each file revision creates a development history of the research document. Project management tools like Zoho Projects can keep versions of files, deadlines, tasks, and milestones of the project.

Doctoral students in the program have experienced varying success with these tools. Listening to student experiences enables growth for both faculty and students. Analysis of the use of tools has sometimes redirected students and faculty to additional choices. Many times, participants initiate the use of various tools to facilitate their own work. Regular communication between committee members and students 
provides opportunity to learn how to use specific tools and troubleshoot problems throughout the dissertation process.

\section{Writing and Research Services}

Courses in research and writing are essential. In 2007, the department hired a full-time instructor to facilitate writing instruction and writing retreats giving distance students focused tutoring and writing time. Online and intensive face-to-face research courses are augmented with research "bootcamps" where a talented methodologist works with students struggling to articulate their methods or develop findings.

\section{Writing Retreats}

Offering writing retreats has become essential for distance doctoral education (Nerad \& Miller, 1997; Williams \& Todd, 2016). Writing retreats help many students clear their minds, reset their goals, and complete large chunks of writing. All writing is essentially "creative" and can be enhanced by the right environment. The most often-used environment has been a retreat center about an hour from the university. The center has nine bedrooms situated on three levels, as well as a kitchen, dining room, bathrooms on each level, a prayer room, a communal sitting room, and quiet nooks for use during the day. Trails through the forest allow guests to wander freely, enjoying the quiet sounds of the forest. Other venues used for retreats included cabins, the library, a boarding academy, and a beach house.

The typical retreat involves nine or ten participants, in a space with separate rooms and common study and meal areas. This setup allows students to engage with others or spend time alone. The participant schedule includes mealtimes, optional daily prayer ritual, and two meetings per day. In the first meeting, groups share daily goals, providing accountability and clarity of purpose. In the evening meeting, participants share accomplishments and hear expert presentations on topics such as managing procrastination, psychological writing blocks, and maintaining motivation and creativity. Participants request one-on-one with a writing coach as desired, and short hikes offered after lunch get participants ready for the next round of work.

\section{Department Support for Research}

Funding and promoting presentations at conferences has motivated many doctoral students in this program toward the completion of their dissertation. Encouraging a student to publish a book review, write a literature review, or present data at a conference helps the student stay motivated and connect to the scholarly community (Kirkpatrick, 2019). Both ad-hoc and systemic focus on capacity development can create better student services.

\section{Conclusion}

The three clusters of strategies described in this article (shared responsibility and commitment, effective communication, and developing departmental and institutional services and technologies for faculty and students) promote student self-regulation. Kelley and Salisbury-Glennon (2016) reported that "incorporating self-regulated learning strategies within doctoral curricula has the potential to improve doctoral candidates' rates of dissertation completion" (p. 97). Because of the individualized, customizable nature of the program, self-regulatory aspects of learning are featured from the start. Participants must 
develop their own learning plans after reflection and narrative writing. They also write substantial reflection papers for each of the 15 competencies required in the program. Throughout the program, four phases of self-regulation are cultivated, as the program requires: a) forethought, planning, and the activation of action; b) monitoring of effort and time; c) control and selection of cognitive strategies; and d) reaction, judgments, reflection, and evaluation (Pintrich, 2000).

Over time faculty have learned how tools and services help participants and fellow faculty stay engaged and progressing in research. Some strategies were arrived at suddenly; others a result of incremental change. Many have been derived from suggestions and pressure from faculty or participants. The strategies reported here have been discovered from more of a trial and error process than strategically planned reengineering of the program. Even through old patterns may seem hard to change, the way in which faculty handles various situations has in fact evolved. One big aspect of this evolution has been the infusing of a network of adjunct faculty into the offered dissertation services. Sharing solutions to help other faculty and students is the next step in growing the program network.

Further research is required to understand and communicate the unique aspects of this competency-based program. For example, how do the Leadership and Learning Groups and Annual Roundtable Conference influence dissertation completion? Further research could explore the effectiveness of methods to provide instruction concerning various research methods - classes, boot camps, sessions during the Roundtable Conference, or individualized and small group help when the dissertation requires it.

Cassuto (2010) stated well that "watching someone tread water in Lake Dissertation (as one clear-eyed student aptly put it) is one of the more painful sights in academe" (p. 1). While Cassuto suggested one way to remove the stigma of an unfinished dissertation would be to create better ways for more students to bow out gracefully, using the strategies suggested in this paper, more can be done to teach students better ways to swim. At a time when doctoral education proliferates in this nation, teaching strategies such as these can help universities and faculty foster the student skills necessary to complete quality dissertations. 


\section{References}

Aghaee, N., J obe, W. B., Karunaratne, T., Smedberg, A., Hansson, H., \& Tedre, M. (2016). Interaction gaps in $\mathrm{PhD}$ education and ICT as a way forward: Results from a study in Sweden. The International Review of Research in Open and Distributed Learning, 17(3). doi:10.19173/irrodl.v17i3.2220

Alaby, J . A. (2002). The end or ends of education? The issue of means and ends of the Andrews University Leadership Program (Doctoral disertation). ProQuest Digital Dissertations database. (3058305)

Ali, A., \& Kohun, F. (2006). Dealing with isolation feelings in IS doctoral programs. International J ournal of Doctoral Studies, 1, 21-33. doi:10.28945/58

Ali, A., Kohun, F., \& Levy, Y. (2007). Dealing with social isolation to minimize doctoral attrition- A four stage framework. International J ournal of Doctoral Studies, 2(1), 33-49. doi:10.28945/ 56

Ames, C., Berman, R., \& Casteel, A. (2018). A preliminary examination of doctoral student retention factors in private online workspaces. International J ournal of Doctoral Studies, 13, 79-107. doi: $10.28945 / 3958$

Baker, C. (2010). The impact of instructor immediacy and presence for online student affective learning, cognition, and motivation. The Journal of Educators Online, 7(1), 1-30. doi:10.9743/JEO.2010.1.2

Berry, S. (2017). Building community in online doctoral classrooms: Instructor practices that support community. Online Learning, 21(2). doi:10.24059/olj.v21i2.875

Bolker, J . (1998). Writing your dissertation in fifteen minutes a day. New York, NY: Owl Books.

Bondy, E., Shannon, D., Eda, M. C., \& Munarriz-Diaz, R. (2017). Recenteringjob-embedded graduate education for practicing teachers. Teacher Education and Practice, 30(1), 38-57. Retrieved from https:// go.galegroup.com

Breen, J . M., \& Martin, J . (2018). Teaching leadership research courses online at the doctoral level: Why we do it and how it works. In L. Hyatt \& S. Allen (Eds.), Advancing Doctoral Leadership Education Through Technology (pp. 155-175). Cheltenham, UK: Edward Elgar Publishing.

Cassuto, L. (2010). Advising the dissertation student who won't finish. The Chronicle of Higher Education, 57(7). Retrieved from https:// www.chronicle.com/article/ Advising-theDissertation/ 124782

Deem, R., \& Brehony, K. (2000). Doctoral students' access to research cultures--Are some more unequal than others? Studies in Higher Education, 25(2), 149-165. doi:10.1080/ 713696138 
Denman, P. M., Corrales, J . M., Smyth, S., \& Craven, K. (2018). From ABD to PhD: A qualitative study examining the benefits of a support group during dissertation in an online doctoral program. The J ournal of Continuing Higher Education, 66(2), 106-114. doi:10.1080/07377363.2018.1469067

Dombroski, K., Watkins, A. F., Fitt, H., Frater, J ., Banwell, K., Mackenzie, K., . . Hart, D. (2018). J ourneying from "I" to "we": Assembling hybrid caring collectives of geography doctoral scholars. J ournal of Geography in Higher Education, 42(1), 80-93. doi:10.1080/ 03098265.2017.1335295

Duesbery, L., Frizelle, S., Twyman, T., Naranjo, J ., \& Timmermans, K. (2019). Developing and designing open border teacher education programs: Case studies in online higher education. J ournal of Educators Online, 16(1). Retrieved from https:// eric.ed.gov/ ?id=EJ 1204380

Fahlman, D. W. (2009). The first doctoral program in distance education in North America. The International Review of Research in Open and Distributed Learning, 10(6), 124-136. doi:10.19173/irrodl.v10i6.711

Faranda, W. T. (2015). The effects of instructor service performance, immediacy, and trust on studentfaculty out-of-class communication. Marketing Education Review, 25(2), 83-97. Retrieved from https:// eric.ed.gov/ ?id=EJ 1130254

Freed, S., Covrig, D., \& Baumgartner, E. (2010). Learning while leading: The Andrews University Leadership Program. J ournal of Applied Christian Leadership, 4(1), 26-55. Retrieved from https:// www.andrews.edu/services/jacl/article archive/ 4 _ 1 spring_2010/05art learning whil.pdf

Fung, A. S. K., Southcott, J ., \& Siu, F. L. (2017). Exploring mature-aged students' motives for doctoral study and their challenges: A cross border research collaboration. International J ournal of Doctoral Studies, 12(1), 175-195. doi:10.28945/3790

Garcia, C. E., \&Yao, C. W. (2019). The role of an online first-year seminar in higher education doctoral students' scholarly development. The Internet and Higher Education, 42, 44-52. doi:10.1016/j.iheduc.2019.04.002

Goodboy, A. K., Booth-Butterfield, M., Bolkan, S., \& Griffin, D. J . (2015). The role of instructor humor and students' educational orientations in student learning, extra effort, participation, and out-of-class communication. Communication Quarterly, 63(1), 44-61. doi:10.1080/ 01463373.2014.965840

Grady, M. L. (2016). Doctoral students in a distance program: Advising and degree completion strategies. J ournal of Academic Administration in Higher Education, 12(2), 49-52. Retrieved from https:// eric.ed.gov/ ?id=EJ 1139130

Harrison, R., Gemmell, I., \& Reed, K. (2014). Student satisfaction with a Web-based dissertation course: Findings from an international distance learning master's programme in public health. The International Review of Research in Open and Distributed Learning, 15(1). doi:10.19173/irrodl.v15i1.1665 
Jairam, D., \& Kahl, D. H., J r. (2012). Navigating the doctoral experience: The role of social support in successful degree completion. International J ournal of Doctoral Studies, 7, 311-329. doi: $10.28945 / 1700$

Kearns, H., Gardiner, M., \& Marshall, K. (2008). Innovation in PhD completion: The hardy shall succeed (and be happy!). Higher Education Research \& Development, 27(1), 77-89. doi:10.1080/07294360701658781

Kelley, M. J., \& Salisbury-Glennon, J . D. (2016). The role of self-regulation in doctoral students' status of all but dissertation (ABD). Innovative Higher Education, 41(1), 87-100. doi:10.1007/ s10755-0159336-5

Kennedy, D. H., Terrell, S. R., \&Lohle, M. (2015). A grounded theory of persistence in a limited-residency doctoral program. The Qualitative Report, 20(3), 215-230. Retrieved from https:// nsuworks.nova.edu/tar/vol20/iss3/5

King, M. F. (2008). Ph. D. completion and attrition: Analysis of baseline demographic data from the Ph. D. completion project (1933042184) [Data file and code book]. Retrieved from https:// cgsnet.org/ phd-completion-project

Kirkpatrick, K. J . (2019). Online doctoral students writing for scholarly publication. Computers and Composition, 52, 19-36. doi:10.1016/j.compcom.2019.01.012

Kumar, S., \& Coe, C. (2017). Mentoring and student support in online doctoral programs. American J ournal of Distance Education, 31(2), 128-142. doi:10.1080/08923647.2017.1300464

Kumar, S., Dawson, K., Black, E. W., Cavanaugh, C., \& Sessums, C. D. (2011). Applying the community of inquiry framework to an online professional practice doctoral program. The International Review of Research in Open and Distributed Learning, 12(6), 126-142. doi:10.19173/irrodl.v12i6.978

Lovitts, B. E. (2001). Leaving the ivory tower: The causes and consequences of departure from doctoral study. Lanham, MD: Rowman \& Littlefield Publishers.

Lovitts, B. E. (2007). Making the implicit explicit: Creating performance expectations for the dissertation. Sterling, VA: Stylus.

Lovitts, B. E., \&Wert, E. L. (2009). Developing quality dissertations in the social sciences: A graduate student's guide to achieving excellence (1st ed.). Sterling, VA: Stylus.

Maki, P., \& Borkowski, N. A. (2006). The assessment of doctoral education: Emerging criteria and new models for improving outcomes. Sterling, VA: Stylus.

Manathunga, C. (2005). Early warning signs in postgraduate research education: A different approach to ensuring timely completions. Teaching in Higher Education, 10(2), 219-233. doi:10.1080/ 1356251042000337963 
Naughton, N., \& Redfern, S. (2002). Collaborative virtual environments to support communication and community in Internet-based distance education. J ournal of Information Technology Education, 1(3), 201-211. doi:10.1.1.106.72

Nerad, M., \& Miller, D. S. (1997). The institution cares: Berkeley's efforts to support dissertation writing in the humanities and social sciences. New Directions for Higher Education, 1997(99), 75-90. doi:10.1002/ he.9907

Newman, I., \& Covrig, D. M. (2013). Building consistency between title, problem statement, purpose, \& research questions to improve the quality of research plans and reports. New Horizons in Adult Education and Human Resource Development, 25(1), 70-79. doi:10.1002/nha.20009

Onwuegbuzie, A.J . (2004). Academic procrastination and statistics anxiety. Assessment \& Evaluation in Higher Education, 29(1), 3-19. doi:10.1080/0260293042000160384

Oregon, E., McCoy, L., \& Carmon-J ohnson, L. (2018). Case analysis: Exploring the application of using rich media technologies and social presence to decrease attrition in an online graduate program. J ournal of Educators Online, 15(2), 1-13. Retrieved from https:// eric.ed.gov/ ?id=EJ 1186019

Pintrich, P. R. (2000). The role of goal orientation in self-regulated learning. In M. Boekaerts, P. R. Pintrich, \& M. Zeidner (Eds.), Handbook of self-regulation (pp. 451-502). San Diego, CA: Academic Press.

Ross, J ., Gallagher, M. S., \& Macleod, H. (2013). Making distance visible: Assembling nearness in an online distance learning programme. The International Review of Research in Open and Distributed Learning, 14(4). doi:10.19173/irrodl.v14i4.1545

Silvia, P. J . (2007). How to write a lot: A practical guide to productive academic writing. Washington, DC: American Psychological Association.

Sowell, R. S. (2008). PhD completion and attrition: Analysis of baseline program data [Data file and coding book]. Retrieved from https:// cgsnet.org/phd-completion-project

Sowell, R. S. (2009). Ph. D. completion and attrition: Findings from exit surverys for Ph. D. completers (1933042222) [Data file and coding book]. Retrieved from https:// cgsnet.org/ phd-completionproject

Sowell, R. S., Zhang, T., Bell, N. E., \& Kirby, S. N. (2010). PhD completion and attrition: Policies and practices to promote student success [Data file and coding book]. Retrieved from https:// cgsnet.org/ phd-completion-project

Terrell, S. R., Snyder, M. M., \& Dringus, L. P. (2009). The development, validation, and application of the Doctoral Student Connectedness Scale. Internet and Higher Education, 12, 112-116. doi:10.1016/j.iheduc.2009.06.004 
van Rhijn, T., Murray, S. H., \& Mizzi, R. (2018). Partners in learning?: A qualitative study of the intimate relationships of partnered mature students in postsecondary education. J ournal of Professional, Continuing, and Online Education, 3(1), 1-24. doi:10.18741/jpcoe36

Violanti, M. T., Kelly, S. E., Garland, M. E., \& Christen, S. (2018). Instructor clarity, humor, immediacy, and student learning: Replication and extension. Communication Studies, 69(3), 251-262. doi:10.1080/ 10510974.2018.1466718

Vygotsky, L., \& Cole, M. (1978). Mind in society: The development of higher psychological processes. Cambridge, MA: Harvard University Press.

Wagner, E., Enders, J ., Pirie, M., \& Thomas, D. (2016). Supporting academic integrity in a fully-online degree completion program through the use of synchronous video conferences. J ournal of Information Systems Education, 27(3), 159-173. Retrieved from https:// eric.ed.gov/ ?id=EJ 1151242

Walker, G. E., Golde, C. M., J ones, L., Bueschel, A. C., \& Hutchings, P. (2008). The formation of scholars: Rethinking doctoral education for the twenty-first century. San Francisco, CA: J ossey-Bass.

Walters, K., \& Henry, P. (2016). Critical analysis of embedded and summative feedback from online doctoral instructors on benchmark major assessments. International J ournal of Learning, Teaching and Educational Research, 15(1). Retrieved from https:// www.ijlter.org/ index.php/ijlter/article/ view/ 231

Walters, K. J ., Henry, P., Vinella, M., Wells, S., Shaw, M., \& Miller, J . (2015). The genre of instructor feedback in doctoral programs: A corpus linguistic analysis. International J ournal on ELearning, 14(4), 525-550. Retrieved from https:// eric.ed.gov/ ?id=EJ 1084306

Williams, J . K., \& Todd, R. H. (2016). Debriefing the interpretive researcher: Spider sniffing with critical friend. The Qualitative Report, 21(12), 2161-2175. Retrieved from https:// nsuworks.nova.edu/tar/vol21/iss12/1

Williams, P. E., Wall, N., \& Fish, W. (2019). Mid-career adult learners in an online doctoral program and the drivers of their academic self-regulation: The importance of social support and parent education level. International Review of Research in Open and Distributed Learning, 20(1). Retrieved from http:// www.irrodl.org/index.php/irrodl/article/view/ 3789

\section{Athabasca} University

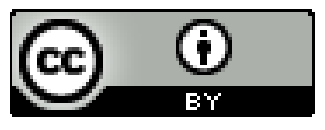

